\title{
Science for Development: Failure in Ghana
}

\author{
Brown-Acquaye, H. A. \\ Department of Science Education, University of Education, Winneba, Ghana
}

\begin{abstract}
The deplorable situation in almost all Third World countries with respect to diseases, poverty, housing and sanitation has prompted governments in these countries to look to science and technology as the panacea to their problems. Their belief rests on the evidence that science is an integral part of modern western society and that the levels of utilization of technology are directly related to their scientific progress. Science and science education are therefore considered to be the vehicles to uplift the Third World countries from their deplorable living conditions. Various strategies have been advanced and introduced by concerned international organizations including UNESCO. The 'Science for Development' model has been highlighted and practiced since the 1960s.Unfortunately realistic results have not been fort-coming. The factors for the seemingly intractable failures of the 'Science for Development' model have been identified in this paper.Among these is the fact that cultural perspectives have been ignored in the implementation of the imported model which is based on western worldview. The recommended constructivist approach to teaching and learning is also based on western worldview. The Ghanaian worldview has been discussed and recommendations made as to how to incorporate this worldview into the teaching and learning of science.
\end{abstract}

\section{Introduction}

In all the developing countries of the Third World, particularly Africa, signs of extreme poverty, poor sanitation, lack of safe potable water, diseases, poor housing, poor health services, high infant mortalities and low life expectancy are very visible. Many governments of the industrialized countries, international NGOs and agencies of the United Nations have expressed concerns for these deplorable situations, which are mostly preventable. Unfortunately the governments of these developing countries are incapable of solving or alleviating the problems. Therefore offer of any assistance from any quarter is most welcome to them. Rarely do they the recipient governments question the motives for the offers, the appropriateness of the interventions and the implications for accepting the offers.

The visible signs of economic and social developments in the western industrialized countries are very attractive and appealing to the developing countries. Of late, quite high on the agenda for fast track development in the developing countries is the notion that only scientific knowledge and exogenous technologies can provide the panacea for their problems. Hitchhiking on to the 
fast lane of the current information technology through the Internet is most desirable.

We are here referring to citizens of the developing countries, the majority of whom are illiterate in science and technology without any access to good potable water or to electricity or to good housing but whose government are bent on importing western technologies and lifestyles. These government officials have been trained in the western industrialized countries and have exogenous inclinations and believe in and accept the concept of science for development, one of the many intervention programmers introduced to stem the deterioration of the prevailing conditions. The UN and its specialized agencies, like UNESCO, FAO, UNDP and other international donor agencies, have championed this concept of 'science for development'.

\section{Science for Development Model in Ghana}

Long before the adoption of the concept of 'science for development', the first President of the Republic of Ghana, Dr. Kwame Nkrumah had some genuine belief in the potency of science and technology to propel Ghana, and for that matter the whole of Africa, into a modern, civilized, industrialized and economically vibrant society. He must have been influenced greatly during his study periods in the USA and Britain.

Immediately after independence in 1957, he initiated many programmers based on science and technology for the rapid industrialization of Ghana. The University of Science and Technology, now named after him, (Kwame Nkrumah University of Science and Technology), was established in 1961.This was followed in 1962 with the establishment of the University College of Science Education, now called the University of Cape Coast, which was mandated to produce only graduate teachers in science for the secondary schools in Ghana. Next to follow was the Ghana Atomic Energy Commission, established at Kwabenya near the premier university, University of Ghana. To support these academic and research institutions, The Ghana Industrial Holding Corporation (GIHOC), comprising of sixteen (16) different industries was established about the same period.

Unfortunately when the government of Dr. Kwame Nkrumah was overthrown through a military coup d'etat in 1966, all the developmental programmers initiated were jettisoned overboard and since then no coordinated programmes based on science and technology have been presented. One would question whether the programmes initiated by Dr. Nkrumah based on science and technology would have been successful had his government not been overthrown. The answer could be 'Yes' or 'No'.

Considering that Nkrumah's government became dictatorial, operating in a oneparty state with him as the life President, the chances of pushing through all the programmes to success are imaginable. He had succeeded to build the Akosombo dam to create the Volta Lake, which up to date is the largest manmade lake in the world, to generate cheap hydroelectric power to be used in the production of aluminum from bauxite.

Although Drori (1998) successfully debunks the notion of a causal link between science and technology for economic progress from case studies of the newly 
industrialized countries (NIC), the case of Malaysia was an exception. Malaysia and Ghana both gained their respective independence status from Britain in the same year, 1957, with Ghana three months earlier. Just as Ghana, under Kwame Nkrumah, had a strong centrally controlled economy in a dictatorial regime Malaysia had a similar environment. In Malaysia, Lewis (1993) reports "access to science education is near universal at primary level and the quality of teaching and material resources is becoming comparable to that found in industrialized countries" (Lewis 1993, p.2). Under Nkrumah's government similar conditions prevailed. Incentives were given to students to study science in the universities. The allowances for students studying were higher than those given to non-science students. Science at that time enjoyed such high legitimacy and status that Dr. Kwame Nkrumah, the President instituted the Ghana Academy of Sciences, which has now been extended to cover the Arts and known as the Ghana Academy of Arts and Sciences.

Now, Malaysia is one of the newly industrialized countries, which has transformed itself since 1971 from a producer of raw materials into an emerging multi-sector economy with electronics as one of its main export products to the USA and Japan. As at the year 2000, Internet users in Malaysia numbered 4.1 million. With a healthy foreign exchange reserves and relatively small external debt, Malaysia is presently way ahead of Ghana which could boast of only 200,000 internet users as at the year 2000. Ghana remains heavily dependent on international finance and technical assistance and with its present economic harassment had no choice but to opt for debt relief under the Heavily Indebted Poor Country (HIPC) programme in 2000.

The differences in the situations in the two countries can only be explained by the political instability in the case of Ghana and the presence of a strong stable government in Malaysia. Also to be noted is the fact that whereas both Ghana and Malaysia had Britain as colonial masters, Ghana retained and still uses English, a foreign language, as the official language and the language of instruction in schools. Malaysia uses a local language, Bahasa Melayu as the official language and that for instruction in schools.

Dr. Kwame Nkrumah strongly believed in Pan -Africanism and worked very hard towards the unification of Africa under a Union government. In his drive for the African Unity he had problems with some leaders of the other newly independent African countries on policy issues and on ideological grounds. Nkrumah had socialist inclinations while some of the other Heads of States, particularly that of Nigeria at that time had capitalist tendencies. The colonial masters, particularly France, did not leave the their newly independent states free to do what they wanted. They had an agenda for them and advocated for 'assimilation 'with France. The British however acted differently leaving their former colonies to their own fates, designs and aspirations. Nevertheless Nkrumah was very skeptical of these former colonial masters and feared that they had schemes to perpetually bind them economically as neo-colonialist states.

A study of the conceptual model of science for development for use in the developing countries would lead one to concur with the skepticism of Kwame Nkrumah. The adoption of the science for development model in Ghana and elsewhere was to frustrate the drive towards the development of a truly 
industrialized Ghana, directing its own research and development programmes. Nkrumah's dreams would have been stillborn.

One of the driving forces for the adoption of the science and technology for development model was the fact that during the 1950s and 1960s development theorists condemned indigenous local knowledge and technology and considered them as inefficient, inferior and indeed obstacles to the fight against poverty, hunger and underdevelopment. These theorists disregarded the mounting evidences for the success of indigenous knowledge and practices in the areas of agricultural production and sustainable development.(Altieri,1987, Brokensha,Warren and Werner,1980; Chambers, Pacey and Thrupp, 1989, Warren,1991,1993).

Warren et al. .report 'Ten years ago, most of the academics working in the area of indigenous knowledge represented anthropology, development sociology, and geography. Today...important contributions are also being made in the fields of ecology, soil science, veterinary medicine, forestry, human health, aquatic science, management, botany, zoology, agronomy, agricultural economics, rural sociology, mathematics...fisheries, range management, and water resource management. (Warren et al. ,1993)

Indigenous knowledge has now been identified to be relevant in preparing development process that is cost-effective, participatory and sustainable.

\section{Contextual Hurdles in the Ghanaian Situation}

Regardless of whatever might have happened under Kwame Nkrumah's government, a very detailed analyses of the implementation of the conceptual model of science and technology for development have been provided by Drori (1998), which, citing from empirical studies clearly 'contradict our everyday notion of science education and the predictions made by the model of science education for development.' From their own studies Kamens and Benavot (1991, p.166) report "it does not appear that official attention given to mathematics and science instruction in primary education is directly related to key indicators of socio-economic development, economic dependence or world system position. The casual link between science education and economic development is at best mythical," Rutherford (1985) still maintains that the continued progress of the developed countries in respect of economy, security, global status and 'attractiveness to human society' would continue to be dependent on science education. Technological innovations are based on cumulative scientific knowledge for which science education is mover. Policy makers generally advance two of the outcomes of science education to include the creation of a technically skilled labour force and a knowledge-based economic growth. To achieve these two outcomes necessitates government control of and coordination between allocation of resources, market needs and educational supply. Guimares (1989) refers to the effective government involvement as the main factor for the economic success of the newly industralised countries (NIC), including Malaysia. Ghana, like other developing countries in Africa has not been able to establish links between university research and industry. Cooper (1973 p, 7), therefore advices African countries 
to study how Japan succeeded to have effective, direct government control over the coordination of education, science and economic policies

The worldwide promotion of the 'science education for development model' by national and international organizations like UNESCO has virtually turned it into a global myth which has prompted the setting up of science tracks in primary and secondary school laboratories and directed the attention of politicians to the issue of science education (Driori, 1998) Some consequences of these may be economic development but as Benavot discusses "the economic effects of science education may have more to do with " hidden" cultural rules, orientations and worldviews being transmitted than the specific scientific content being taught' (Benavot ,1992 p.173). In effect, serious consideration of the 'science education for development' may in the long run be found to be "just mere words" which reflect and promote a particular social context. The policy directives that may emanate from the adoption of the model may include the writing of text-books in English with foreign consultants, choice of pedagogical instructional materials recommended by the foreign consultants and the use of these teaching and learning materials to infuse certain facts and western worldviews in the pupils.

After the failure of externally induced and prepared development initiatives, attention is now directed to the participation of the indigenous and local groups in developing strategies that fit into their local conditions. Cultural barriers are mentioned among some social mechanisms that impede the success of the science for development model and Drori (1998) points out that such barriers impede the transfer of knowledge - thus knowledge that was created in a particular cultural context.

Many cultural barriers do exist in the Ghanaian situation to stifle the implementation of the science for development concept. According to Benavot (1999, p.173) 'the economic effect of science education may have more to do with "hidden" cultural rules, orientations, and world views being transmitted than with the specific content being taught. 'The current push towards globalization necessitates worldview standardization of scientific education curricula and isomorphism (Drori, p.59). The role of science education, according to Drori is twofold within the scheme of science education for development. These are

a). to shape positive attitudes towards modernization and

b). to train candidates in science and technology and prepare them for higher education and for sophisticated production roles (Drori, p.59).

Within the science for development model there is provision for professional training and for the provision of local skilled labor for the economy. This is based on one of the four major assumptions for the model and considers the role of science education as providing a lead to the preparation of scientificallyand technically- skilled labor force. With such skilled personnel it was expected that industrialization and economic progress would follow. Unfortunately this conceptual frame of science for developments is based on western science whose worldview, according to Cobern is grounded on the following three imperatives of modern western society: 
i. The imperative of Naturalism - all phenomena can ultimately and adequately are understood in naturalistic terms;

ii. The scientific imperative - anything that can be studied, should be study;

iii. The technocratic imperative - any device that can be made, should be made. (Cobern, p.20)

From the above statements it is evident that the single logical goal of the western worldview is the material well being of the people. This position is captured by the statement of America's most prestigious scientific organization, The National Academy of Science:' In a nation whose people depend on scientific progress for their health, economic gains, and national security, it is of utmost importance that our students understand science as a system of study, so that by building on past achievements, they can maintain the pace of scientific progress and ensure the continued emergence of results that can benefit mankind" (NAS, 1984,p.6)

The current trend of industrial and economic development in the western countries clearly point to the adherence of the principles advocated by the American National Academy of Science. Some Americans are concerned about the one-directional outlook of economic and social development based solely on science and technology. Sadly their voices do not go far enough and their admonitions about the fact that there is more to life than economics are not heeded. Aleksandr Solzhenitsyn, the Russian writer has commented

as creature comforts continue to improve for the average person, so spiritual development grows stagnant. Surfeit brings with it a nagging sadness of heart, as we sense that the whirlpool of pleasures does not bring satisfaction, and that before long, it may suffocate us...No, all hope cannot be pinned on science, technology, economic growth (1995,p.89).

Drori regards the science for development model to have its theoretical foundations on the structuralist-functionist modernization theory, which divides national development into stages. The hierarchy for the nation states has the developed countries on top with the Third world countries at the bottom. It is further stipulated that situations and events can be transferred from one nation-state to another. It is therefore possible for the least developed countries (LDCs) to follow in the footsteps of the developed countries to achieve the standards and economic prosperity and social liberties of the advanced developed countries. Since the progress of the advanced developed countries were achieved through the mechanism of science and education, similar progress could be realized through science and education.

The community into which the science for development model has been introduced is one where the people, the Ghanaians, some of whom have had contacts with western culture are still firmly attached to their traditional cultural background. They still practice profound ancestral worship and veneration .The belief is that ancestors offer protection to their descendants and in return are propitiated. This is unacceptable in the western culture whose science is being introduced. The relationship between elders and their juniors is still dependent on the respect for the aged. Children are expected to maintain low profile in the presence of their elders and are not expected to argue with them, since age has an ascribed social status in the Ghanaian community. The 
constructivist theory which is the basis for science teaching and learning demands that the students construct their knowledge from active dialogue with their teachers, be very objective in their reasoning and be bold to raise questions about things they do not understand. This practice will not find favour in the Ghanaian context and will pose serious obstacles in the learning process of the Ghanaian science students.

The respect for age and authority, which are validated by traditional religious beliefs, will be confronted by the practice of constructivist theory in learning science. Since religion plays a major role in the daily activities of the Ghanaian, any programme, which plays down on the religious aspect, is bound to be rejected. For any outside program to be accepted the cultural context of the beneficiaries must be considered.

One of the main causes for the failure of the science for development concept in Ghana can be deduced from Cobern's statement 'accepting the tight, linear science -technology-economic development (STD) model squeezes out nonscientific ways of knowing and in doing so, creates for science (in its scientific form) a privileged status in society. As this occurs there is increasing pressure for other aspects of culture to conform to scientific thinking. Any areas of resistance come to be viewed as deficiencies because the areas of resistance impede the takeover by scientific rationality.' (Cobern, 1998, p.20-21)

It would be naïve for any one to think that the advocates of science for development in the developing countries would sit down unconcerned to have their efforts thwarted by local cultural practices. They are not only to transfer scientific knowledge but through that to impose the western culture on the people. According to Basala, the first task pertaining to the subject of world view is that;'a resistance to science on the basis of philosophical and religious beliefs must be overcome and replaced by positive encouragement of scientific research. (Basala, 1967, p.617).

This position is further given support by Poole who state;"it is difficult to see how the less advanced societies can achieve the high living standards at which they aim without assimilating large portions of the western conceptual systems, not least those concepts of scientific significance') Poole, 1968 p.57). In his book, The Stages of Economic Growth, Rostow (1971) discouraged the use of an indigenous scientific enterprise from the scratch when according to him, it was much easier to import a highly ready made and advanced body of scientific knowledge from abroad. The question to be answered is for whom would that knowledge be used, to whose benefit and for what purpose? 'Acceptance of this philosophy would only end up in making neo-colonialist states of these nonscientific developing countries. This exactly is the hidden agenda of the science for development concept and was to be a prelude to the current globalization movement.

The culture of western school science or worldview is described by Cobern as "scientist and one which alienates many students" (Cobern 1998.p19). Based on the logico-structuralism model devised by Kearney (1984, p.106), Cobern presents the descriptors of the seven categories that comprise a world in a tabular form, Table 1. 
Table $1 \quad$ Example Descriptors for Worldview Categories

\begin{tabular}{|c|c|c|}
\hline \multicolumn{3}{|c|}{ Example descriptors for worldview categories } \\
\hline $\begin{array}{l}\text { Worldview } \\
\text { Categories }\end{array}$ & Scientistic Descriptors & Alternative Descriptors \\
\hline The Other or NonSelf & $\begin{array}{l}\text { Materialistic, reductionistic, } \\
\text { exploitive }\end{array}$ & $\begin{array}{l}\text { Holistic, social/humanistic, aesthetic, } \\
\text { religious }\end{array}$ \\
\hline Classification & Natural only & Natural, social, supernatural \\
\hline Causality & $\begin{array}{l}\text { Universal, mechanistic, } \\
\text { structure/functional }\end{array}$ & Context bound, mystical, teleological \\
\hline Relationship & $\begin{array}{l}\text { Strict objectivism, non- } \\
\text { personal }\end{array}$ & Subjective, personal \\
\hline Self & $\begin{array}{l}\text { Dispassionate, independent, } \\
\text { logical }\end{array}$ & Passionate, dependent, intuitive \\
\hline Time and Space & Abstract formalism & Participatory-medium tangible \\
\hline
\end{tabular}

The descriptors were arrived at from extensive research and examination of the cultural form in which western science is embedded and compares them with the descriptors based on non-western worldviews. Cobern rightly deduces that the western scientific view of the world as presented in the classroom is often materialistic, reductionist and exploitative. (Cobern, 1998, p.19).

These descriptions are explicit in the traditional western dominance theme about and a Japanese observer comments;' in the western idea, man was not an ordinary part of nature. He was a specially privileged creature, and nature was subordinate to him... he was the master of the natural world, which was at his disposal to analyze, examine and make use of ... since the natural world and the whole universe were manifestations of God's creation, the study of it was not only a useful but also a highly esteemed endeavor ... Such an outlook provided some of the important religious motivation which fostered the development of modern science in the western world." (Watanabe, 1974, p.280)

The Ghanaian's relationship with the 'other' or the 'non- self' is holistic, humanistic, religious and completely in contrast to that of the western world view.

According to Ogunniyi, the world view of an African is monistic/vitalistic, while those of the western scientist is irrational/impersonal.(Ogunniyi,1983, p.84).With respect to the universal causality ,Okeobukola and Jejede infer that the African's attitude to cause and effect is teleological while it is mechanistic for the western scientist;; 'causality is seen in terms of volition and not in terms of mechanistic laws. Things do not just happen in the traditional African society: events have a cause, but that cause is seen in personal terms" (Okebukola and Jejede, 1988, p.3) Within the concept of the science for development, the Ghanaian student is expected to be objective and non- 
personal, which are not part of his/her descriptors in the logico-structural model of world view.

A story is told of a father in a Ghanaian farming community who consistently refused to allow his only child, a boy of 12 years to accompany his friends to the forest. On the day that he allowed his son to go with his friends, there was an accident in the forest. A big tree fell and hit his son on the head, killing him instantly. The following questions agitated the mind of the grieving father:

i. Why did he allow the son to go to the forest with his friends on that particular day although he had consistently refused the request on previous occasions?

ii. Why did the tree fall, not on anyone in the group but on his only child on the very first day that he joined the group

iii. Who fell that tree which was standing erect.

The cause of death in a Ghanaian community is an important issue for consideration since a tragic death through accident is regarded 'unclean' and could be due to gross and persistent violations of the sanctions of the gods and ancestors. Ghanaians believe that babies are a creation of God and that after birth babies are given to families on loan by God and for specific purposes. Parents therefore go to all extent to find out from the deities about the character and nature of their babies, the purpose of their creation, their destiny or what the babies would become.(Kuamuah,2000,p.8).

This grieving father would be worried to find out whether a god or a spirit and what would have been his sin to make him incur such calamity inhabited the tree. His dilemma would not be answered from purely scientific, materialistic, reductionist, mechanistic, strictly objective, non-personal and dispassionately independent logical ways of thinking that would have been the method of the western scientist.

The western scientist presents his world view as superior to that of the nonscientist and it is this assumed privileged status of the western world view that prompted the Maori intellectual, Linda Smith to write it appalls us that the west can desire, extract and claim ownership of our ways of knowing, our imagery, the things we create and produce, and then simultaneously reject the people who created, developed those ideas, and seek to deny them further opportunities to be creators of their own culture....(and) deny them the validity of their own knowledge. (Smith 1999,p.1)

It must be realized that the western worldview had evolved over many centuries from the $16^{\text {th }}$.to the present and had resulted in the present materialistic and non-spiritual attitude where power and dominance of nature and other cultures is the goal of development. Based on the logico-structural model of worldview one can identify worldviews that are different but yet scientifically compatible and acceptable. If this existence of scientific pluralism were acknowledged and accepted, wholesale export of a foreign worldview would be discouraged. Hewson (1988, p.317) has recommended that 'rather than continuing to encourage the west to donate scientific knowledge and skills to developing countries, a different approach might usefully be taken. 
Critical dialogue between the west and the developing countries could promote conceptual change of the knowledge bases of both and allow for the emergence of a new type of science that is effective in meeting specific problems at a range of levels in developing countries, and possibly in the west as well. (Hewson, 1988,p.317).

This dialogue would have to take into consideration the religious nature of the Ghanaian and therefore take note of what Orzel warns against 'Now everywhere is a market. There is nothing, which has not become a commodity that can be bought and sold. The market with its impenetrable mechanism, its shrines, banks, production and consumption armies, serve as a god for those who have gone astray from religion' (Orzel, 1992,p.32.)

If science were to accept that there is room for other views, room to ask questions and room to accommodate other perceptions, then it can grow into a truly universal discipline, which will receive back most women, and men who have rejected, science. (Stocklmayer p.8).

In her book 'Whose Science, Whose Knowledge?', Sandra Harding (Stocklmayer 1991. p.8), advocates for science which is more diverse and is more embracing of other world views. Cobern opines, "Science educators speak of authentic science in the classroom, and science instruction that model science. Science educators speak of fostering in students a scientific worldview, which presumably means the worldview of scientists. However, the point... is that the scientists drawn from the world over do not compose a single, homogenous group of people that can accurately be said to have a single worldview. If that is the case, then the goal of authentic science in the classroom means that worldview study in science education must include a focus of the worldviews of scientists in culture. Failing to do so means pursuing a scientific outlook out of context."

If indigenous knowledge systems would not be described as 'backward, naïve or misconceptions, but rather recognized as alternative conceptions, a lot of progress would have been made in respect of science education in the developing countries and their local scientists would gain the confidence of applying their to the solution of the local problems. They would not wait for solutions to come from outside their local domain. Imposing a specific foreign world view on any nation because of their need for economic and social development will not achieve much because of the entrenched cultural backgrounds of the recipients and their inherent attitude to resist external influences and encroachment on their cultures.

The science and technology concept has failed in Ghana because of the failure of the government to see beyond the 'catching up' syndrome that refuses to consider building on the Ghanaian cultural background. The whole exercise of catching up on development is a mimic of western development. Mahatma Ghandi is reported to have said of a woman trying to behave as a man thus "she can run the race but she will not rise to the heights she is capable of by mimicking men". The government of Ghana fails to realize that any particular technology exists within and is intimately related to a particular social context. The Ghana sages have said 'It gives the teeth of a child more strength to 
struggle for nought with the hard bone of a chicken's foot than to fiddle for sweetness with a piece of soft sugar cane'.

\section{The Language Factor}

A major problem with the teaching of science is with its communicating. The possibility of communicating the wrong idea is very high and this would leave the students more puzzled than before. The Ghanaian students already consider science to be 'hard' and difficult to understand and also not very important for real life. Learning of science is considered to be done by rote acquisition of facts and formulae, which have no bearing or relevance to their daily life. Learning of science is made more difficult if it has to be taught in English, a second language, by teachers whose knowledge of the English language is shallow.

In all learning processes, the medium of instruction has a major role to play since it is related to both attitude and cognition. In Ghana knowledge of the English language commands a prestigious position as it provides access to jobs and economic power. The image of science for development is thus complicated by the need to gain control over the English language.

A lot of studies have been done on the challenges of learning science through a second language like English. Strevens (1980) has two categories of learners of science using English as the medium:

i. Those who have come to an English -speaking country having received part or all of their schooling in another language and

ii. Those who are citizens of a multi-lingual country where the language of official communication is English and who are officially taught at school through the medium of English

The Ghanaian falls into the second category and encounters English for the first time at school. Textbooks are written in English, class assignments are to be done in English and examinations are also conducted in English. Krashen (1982) distinguishes between language learning and language acquisition and associates those in Strevens' second category, like the Ghanaians to be more engaged with language learning. Because of the slow and ineffective start with the second language, there is bound to be a mixture of language acquisition and language learning for this category.

Cummins (1980) has, however, noted a contrast between conversational and academic language proficiency for the second category. This group has difficulty in expressing ideas in writing. They can articulate an oral understanding of a concept but have difficulties in communicating these ideas on paper. The members in this group are therefore found to give the general impression of poor performance at written examinations. From his studies Rutherford (1993) considers problems associated with expressing scientific ideas in African languages more to do with vocabulary, logical connectors and multiple meanings of words. Conceptual difficulties in learning science have also been identified. Inglis(1993) has observed that the quality of the writing skills of students are related to their conceptual understanding of the content of the science assignment. The inference is that poorly written science assignments may be due either to poor language proficiency or to weak conceptual 
understanding. Similar observation has been made by Rollnick et al. (1992) who include also traditional thinking and culture as impacting on science learning. Rollnick(1988,p.232) states: 'the student in Africa has one name which is used at school and another name which is used at home. There is one type of acceptable behaviour at school and one at school. There is one type of dress for school and one for home. There is a language for school and a language for home. Because of this the student too becomes two people.' Language is indeed part of the learner's culture and words and meanings are based on cultural backgrounds.

Oral transmission as a means of passing knowledge from generation to generation also has effects on learning science. Certain conventions are important in the oral transmission as they mediate thought processes and may not be compatible with or acceptable in scientific writings. Although literacy is on the increase among Ghanaians the rate is too slow to overshadow oral transmission. Prophet and Dow (1994) from their studies in Botswana have observed that scientific concepts attainments are greatly influenced by the language of instruction. Collison (cited in Rollick) has also noted that the Ghanaian pupils made higher cognitive level statements in class discussions when they used the local home language than when they use $d$ English language, the official language of instruction.

From a theoretical consideration of the role of language of instruction in science teaching and learning, it is evident that in a situation where that language is a second language for the students, there would be considerable difficulties in the teaching and learning processes. These difficulties would impact negatively on the progress and success of the concept of science and technology for development in Ghana.

\section{Alternative Strategies}

The need to look at other directions and policies, which take due cognizance of the cultural differences in order to bring real developments to the people of the developing countries is long overdue. In so doing one should not ignore the pervasive efforts of the western sponsored institutions like the World Bank/IMF and their collaborators in various schemes to execute their hidden agendas under the guise of globalization, standardization and homogeneity of science curriculum in primary and secondary schools.

An African proverb has it that "when lost, it is better to return to a familiar point before rushing on." The perception that anything indigenous is synonymous with lack of progress and innovation must be vehemently rejected. It is now generally accepted that successful development strategies must have indigenous knowledge as a component in the planning.

Africa presently stands at a crossroad in search of a new vision of development aimed at eradicating the preventable diseases, alleviating the poverty and establishing human rights and the promotion of human dignity based on traditional practices and culture. The affluence of globalization should in no way blindfold the political leaders since it is just a minority in the society who are benefiting. It is unfortunate that some aspects of the colonial heritage, in particular the educational system with the science that accompanied it have become an albatross on the necks of governments in most African countries. 
'Development from below is for many reasons, a more productive approach than that from above, and ...an essential ingredient is indigenous knowledge...To incorporate in developmental planning indigenous knowledge: is a courtesy to the people concerned; is an essential first step to successful development; emphasizes human needs and resources, rather than material ones alone; makes possible the adaptation of technology to local needs; is the most efficient way of using western "Research and Development" in developing countries; preserves valuable local knowledge; encourages community self-diagnosis and heightens awareness; leads to a healthy local pride; can use local skills in monitoring and early warning systems; involves the users in feedback systems , for example, on crop varieties.

These positive reasons -together with the negative reasons, such as the likelihood of failure without using indigenous knowledge- constitute a strong case for incorporating this knowledge in development programs' (Brokensha et al. 1980:7-80)

From their study into indigenous systems of innovation in East Africa Bertelsen and Muller (2001) point to the existence of two systems of learning in Tanzania, one in the formal sector and the other in the informal sector. They draw attention to the fact that efforts to transfer scientific and technical knowledge from the western industralised nations to the developing countries without concern for their cultures would fail. Pradhau advices: 'science education, in any country, is certainly a systematic and sustained attempt at communication about nature between a scientific and a non-scientific or a partially scientific community and as such it should be particularly sensitive to the attitudes and presuppositions of both the scientist and the student' (Pradhau, 1967, p.649.)

Cobern agrees 'science content is science content, regardless of culture, but not so much with its communication. Communicated science, which includes science education, is embedded in culture' (Cobern, 1998, p.18).

\section{Knowledge acquisition in the Formal Sector}

In Tanzania it was observed that the euro-centric perception of what knowledge is about is the trust in the formal system of knowledge acquisition. Similar situation can be found in Ghana. Wackerhansen (1999) has identified five 'dogmas' as the basis for knowledge acquisition in the western industralised countries:

a. Knowledge is understood as being explicit in something that is being or can be articulated in a linguistic way. Thus knowledge can be externalized in relation to humans. It becomes an object, something that can be moved around, stored, sold or bought.

b. Human qualifications are based on rules that can be described. These rules are based on or developed from a rational professional expertise and can be written in a set of regulations.

c. Combining the above two perceptions, professional competence is seen as being generated from explicit knowledge combined with rule-based skill to solve problems in ones professional domain

d. Possession of a relevant data bank of knowledge related to a profession is required in order to become a professional craftsman. 
e. The single individual is the subject for learning and competence. The one that learns is the one who has the competence.

These five 'dogmas' are used to guide the training of craftsmen in the formal sector. With these perceptions formal training as craftsman has become institutionalized in an educational system where practical traineeship has gained less and less attention in Tanzania. The informal apprentice system is still around although it is not part of the formal educational system this situation also prevails in Ghana.

\section{Knowledge Acquisition in the Informal Indigenous sector.}

The knowledge acquired by craftsmen in the informal sector is based on experiential and implicit learning with a high degree of tacit knowledge. Although competence is being developed there is no documentation and there is very little verbalization. In such a system the apprentice learns to produce a range of specialized products and also learns to cooperate with other craftsmen, customers and to move within the community and society as such. The learning that takes place through experience is grounded in a mentor-protégé system for skill transfer.(Nsana,2001).In order to survive in the rural areas and in the towns the craftsman must depend on an acquired ability to navigate in a cultural, social and family networks and settings. In a rural setting there exists diversity, complexity and high degree of uncertainty. To survive in this setting the craftsmen must acquire other different skills through different types of informal apprentice systems. They should be capable of more than one craft. This will depend on the quality of the crafts as well as the proportion of basic knowledge and local time and place knowledge that are required for that particular craftsmanship. The core norms and values are determined according to the basic understanding of how, why and when people in the community act. Learning and education systems development in the informal sector are therefore more about developing the skills and qualifications strictly required for a particular craft. The informal knowledge depends on personal qualifications acquired by and embedded in that person who has learnt that craft.

\section{The Potential for Development}

Mobilization of indigenous knowledge and technology are very necessary for social transformation. For example, the technology of the village blacksmiths is extremely labour demanding, cumbersome and low level productive. But for as long as the agricultural technology is based on relative simple tools there will always be a need for the intimate knowledge of the blacksmiths about the particular crops and soils of the particular local areas. Whether animal drawn ploughs or other implements will be introduced will depend on the ability to have a localized adaptive technological capability and repair capacity.

Admittedly, the application of modern western science and technology for development is showing success in the western countries because of the milieu they are operating. In the present era of globalisation, the future of developing countries is in jeopardy as it is very easy to be marginalized and thus left in more poverty, disease and lack of social development if the cultures and practices of the developing countries are replaced by foreign cultures through schemes developed elsewhere and imposed on the poor developing countries. 
The experience of the Japanese in not succumbing to the encroachment on their culture by the west through western science for development is an example worthy of emulating. The Japanese accepted that science is a constructed artifact, which must be culturally based. This was their basis for their success." Science to them is universal for other people and as such science education must be an interpretation based on the Japanese image of science and what they, the Japanese think it should be. There is, thus, no culture-free interpretation of science or science education. The Japanese accepted that the ideas and methods of western science could be adequately taught in Japanese schools within the traditional Japanese worldview of nature, even though the results may appear strikingly different from the western practice of science education" (Ogawa,). Ghanaians have to learn from the Japanese in their border crossing into western science for development. The statement exemplifies the Japanese attitude 'I may wear a western suit, but I have a bamboo heart' The Ghanaian should be taught to say 'I may wear a western suit but I shall retain my neem heart'.

\section{Conclusion}

The present situation in Africa with regard to development is indeed very bad and has prompted President Thabo Mbeki of South Africa to designate this period as the moment of the African Renaissance in which we are our own liberators' (Mbeki, 1999). The South African president elaborates further by saying "An essential element of the African Renaissance is that we must all take it as our task to encourage her, who carries this leaden weight, to rebel, to assert the principality of humanity -the fact that she, in the first instance, is not a beast of burden, but a human and an African being'. (Mbeki, 1999) In this context science educators and technologists have a major role to play if 'She' is not to be seen as a 'beast of burden but a human and an African being". The call to rebel must be taken seriously. The rebellion must be in the mind first, relieving the mind of considering the number of four-wheel -drive cars on the road, the number of cellular phones in the system, the number of people with access to the Internet etc as indices of development. These are all desirables but not necessary in the face of the extent of diseases in the community, lack of good quality potable drinking water, good housing shelters and the unacceptable extent of poor sanitation in the communities in Africa. African scientists must stand up and inform governments that just establishing the structures of western democracy in Africa do not of necessity lead to the eradication of diseases, provision of good drinking water etc. The amounts spent on the establishments of these structures of western democracy to ensure freedom of speech, rule of law, separation of powers etc. with the concomitant provision of fringe benefits for the politicians reveal lack of concern for the ordinary person whose needs are very basic and ordinary. These basic needs are not outside the capabilities of the local scientists and technologists to provide. In Ghana for example the problems associated with food are. not in the production but are related to post harvest losses. It is known that a lot of research work has been done and documented by the Food Research Institute in Accra. Similarly the innovative craftmanships displayed by the artisans at Suame magazine in Kumasi should put Ghana way ahead in technological practices to solve basic problems associated with housing, agricultural machines, and transport. Relying on imports is not a way of 'encouraging her 
who carries the weighty burden to assert herself '(Mbeki 1999). According to Rogers:' We cannot change, we cannot move away from what we are, until we thoroughly accept what we are' (1980.). What are we now? One may ask. We are very poor, messed up and entangled in preventable diseases, which makes one to wonder whether it is worthwhile to bring forth children, as on the first day of birth, these children become sources of sorrow not of happiness. The pictures of these dying babies become the object of ridicule in the western electronic and print media.

Universities and other tertiary institutions in Africa cannot stay aloof in this in this fight against poverty, diseases etc. As Tema (2002) recommends Research students imbued with the spirit of contributing knowledge that would help rebuild their countries, would reject the idea of conducting research solely on the basis of the supervisor's agenda. They would have the boldness to present research proposals that ask authentic questions. They would also feel challenged to respond through research to statements by researchers who have attempted to compare African and modern Western thinking.' Tema continues "the African scholar also has to take up the challenge of bringing traditional African knowledge into the classroom and to conduct his or her own critical analysis...African researchers should also take it upon themselves to explicate African beliefs and conceptions, such as those that conflict with modern medicine."

Irzik(1998) is of the conviction that the business of science is to supply the facts about the world from the western perspective, but not to indulge in the values and value judgements. Bulac (1998) challenges the needs for the products of western technology. He asserts that people have lived for centuries without TVs, refrigerators, computers, etc. Products which are not necessary for survival are being promoted by western powers to encourage consumerism of their products and indirectly make the developing countries dependent on western economy and technology through neo-colonialism.

There is every indication of hope for the development of the third world countries if the advocates of globalisation would appreciate what Irzik admonishes "that the way to acquire knowledge of the world is not independent from the institutions, practices and discourses that produce it and does change historically". This statement is indeed a restatement of Feyerabend's pluralistic relativism that states 'every culture, every nation can build a science that fits its own particular needs' (Feyerabend, 1989). Ogawa (1989) also states 'every culture has its science'. There are as many kinds of science as there are societies which makes it irresponsible and without any grounds for any one to claim a cognitive superiority over the others. The solution lies in recognizing your own and upholding it there is nothing wrong about learning other worldviews and incorporating the good and acceptable portions into one's own.

Wholesale importation of development plans, devised and drawn within the western worldview will never succeed in any developing country. The indigenous knowledge which is undervalued and which is disappearing needs to be resuscitated and be made the pivocal resource in the search for development. This way is technically the easiest and most convenient. It is up to the politicians and their advisors to realize this and accept it. Rome was not built in a day. If it is realized that indigenous knowledge is derived within the 
immediate context of the livelihoods of the people and as such it is dynamic there would be constant modifications as the needs of the people and society change.

President Olesegun Obasanjo of Nigeria, in his plenary address at the World Education Forum declared in part The global village of the new century cannot afford (for reasons of equity, equality of nations and world security) to have impoverished ghettos in its fringes. It is, in fact in the interest of the richer countries to come urgently to the assistance of the poorer ones. The operative word is assistance-that is technical, logistic and financial help in articulating endogenous ideas for development and seeing them to fruition. as well as in strengthening individual and institutional capacities.'

\section{References}

Altieri,M. (1987); Agroecology: The Scientific Basis of Alternative Agriculture. Boulder,CO Westview

Basala, G. (1967); The spread of western science. Science, 156,611-622

Benavot,A. (1992). Curricular content, educational expansion, and economic growth. Comparative Education Review, 36(2):150-174

Bertelsen,P; and Muller,J. (2001) Who Are The Ignorant: Current Transformations in Tanzanian Indigenous Technology Systems. Paper for Nordic Africa Days. The Nordic Africa Institute. Uppsala

Brokensha, D; Warren, D. and Werner, O; (Eds.) (1980) Indigenous Knowledge Systems and Development. Lanham MD: University Press of America

Bulac, A. (1995) Quoted in Irzik G. Philosophy of Science and Radical Intellectual Islam in Turkey In W.W. Cobern (Ed.) Socio-Cultural Perspectives on Science Education: An International Dialogue. Kluwer Academic Publishers. Dordretcht.The Netherlands.

Chambers, R; Pacey, R; and Thrupp, L. (Eds.) (1989). Farmer First: Farmer Innovation and Agricultural Research. London: Intermediate Technology Publications.

CIA-The World Factbook (2002) Malayasia

CIA-The World Factbook (2002), Ghana

Cobern, W.W. (1998) ; Science and a Social Constructivist View of Science Education. In W.W. Cobern (Ed.) Socio-Cultural Perspectives on Science Education: An International Dialogue .pg. 7-23. Kluwer Academic Publishers. Dordretcht. The Netherlands.

Collison, C.O, Cited in Rollnick ,M; The influence of language on the second language teaching and learning of science .In W. W. Cobern (Ed.) SocioCultural Perspectives on Science Education: An International Dialogue.pg.121-137. Kluwer Academic Publishers,Dordretcht, The Netherlands. 
Cooper, C; (1973). Science ,technology and production in the underdeveloped countries: an introduction. In C. Cooper(Ed.) Science, Technology and Development.pg. 1-18. London Frank Cass

Cummins, J; (1980). The cross lingual dimensions of language proficiency: Implications for bilingual education and the optimal age issue. TESOL Quarterly 14:175-187.

Driori, G.S. (1998) A Critical Appraisal of Science Education for Economic Development. In W.W. Cobern (Ed.) Socio-Cultural Perspectives in Science Education: An International Dialogue. pg. 49-74 Kluwer Academic Publishers.Dordretcht .The Netherlands

Dudgeon, P; (1998) .Valuing the wisdom of the past . In L. Byrski (Ed.) The Way Ahead: Prominent Australians talk about the future of our Nation. New Holland, Sydney.

Feyerabend, P. (1991). Preface to the Turkish Translation of Science in a Free Society. Translated by Ahmed Kardam,. Ozgur Bir Toplumda Bilim. Ayriviti Yayinevi; Istanbul

Guimaraes, F; (1989) .Technology policy in newly industrial countries: A Brazilian perspective. Science and Public Policy, 16(3) ;167-175

Hewson, M.G. A'B ;(1988). The ecological context of knowledge: implications for learning sciences in developing countries., Journal of Curriculum Studies. 20(4)

Horton, R; (1982) Learning and Teaching Science. South African Journal of Science. Vol.76, 397-403

Inglis, M; (1993) An investigation of the interrelationship of proficiency in a second language and the understanding of scientific concepts. Proceedings of the First Annual Meeting of the Southern African Association for Research in Mathematics Education. Grahamston, South Africa; Rhodes University.

Irzik, G; (1998) Philosophy of science and Radical Intellectual Islam in Turkey. In W.W. Cobern (Ed.) Socio-Cultural Perspectives on Science education: An International Dialogue. pg.163-179. Kluwer Academic Publishers.Dordretcht. The Netherlands.

Kamens, D.H. and Benavot, A; (1991). Elite knowledge for the masses: The origins and spread of mathematics and science education in national curricular. American Journal of Education ,99(2), 137-180.

Kearney, M. (1984) Worldview. Novato. CA. Chandler and Sharp Publishers Inc.

Krashen,S.D. (1982) Principles and Practice in second language acquisition. Oxford, UK: Permagon Institute of English

Kuamuah, T; (2002) .Outdooring of Babies-The North Eve Example. AMAMMRESEM; The Ghana Folklore Magazine Vol.1 pg. 8. Accra.

Lewis, K.M. (1993); Planning policy on science education in developing countries. International Journal of Science Education; 15(1) 1-15 
Mbeki. T; (1999) Africa- The Time Has Come. Tafelberg Publishers Ltd. Cape Town

National Academy of Sciences (1984). Science and Creationism: a view from the National Academy of Sciences. Washigton DC. National Academy of Sciences

Nkrumah, K; (1965) ; Neo-colonialism :the Last stage of Imperialism. New York International Publishers. New York

Nsana, B. (2001). Apprenticeship Systems and Entrepreneurial Skills Development- A study of Tanzanian rural and urban micro and small enterprises. Department of Development and Planning. Aalborg University

Obasanjo, O. (2000) Paper delivered at the Final Plenary Session of the World Education Forum,Dakar

Ogawa, M; (1998) A cultural history of science education in Japan. An epic description. In W.W. Cobern (Ed.) Socio-Cultural Perspectives on Science education: An International Dialogue. pg 139-162. Kluwer Academic Publishers. Dordretcht. The Netherlands

Ogunniyi, M. B. (1983). Relative effects of a history/philosophy of science course on student teachers' performance on two models of science. Research in Science and Technological Education. !(2) 193-198

Okeobukola, P.A. and Jegede,O.J. (1988). Traditional cosmology and its influence on students' acquisition of the skills of scientific observation. Paper presented at the Annual Meeting of the National Association for Research in Science Teaching, Lodge of the Four Seasons, MO

Ozel,I; (1992) Three Issues: Techne-Civilization-Alienation. Cidam Yayinlari: Istanbul

Poole, H.E; (1968) The effect of urbanization upon scientific concept attainment among Hausa children of Northern Nigeria. British Journal of Educational Psychology. 38, 57-63

Posner, G.J. ; Strike, K.A; Hewson, P/W. \& Gertzog ,W.A. (1982). Accommodation of Scientific Conception. Science Education 66(20) 211 227

Prather, J.P (1990); Tracing Science Teaching. Washington DC. National Science Teachers .Association

Prophet ,B. and Dow, P (1994) Mother tongue language and concept development in science .Language, Culture and Curriculum, 7(3) :205-216

Rogers,C. (1980) On Becoming a Person. Constable \& Co. London

Rollnick ,M. S.; White ,M; and Dison ,L; (1992) Intergrating writing skills into the teaching of chemistry: an easy task with bridging students. Proceedings of the Annual Conference of the South African Association for Academic Development. Port Elizabeth, 3-5 December

Rollnick,M.S. (1989). The influence of language on the second language teaching and learning of science. In W.W. Cobern (Ed.) Socio-Cultural 
Perspectives on Science Education:An International Dialogue. pg.121-137. Kluwer Academic Publishers Dordretcht The Netherlands.

Rostow, W. W. (1971) The shapes of economic growth: a non-communist manifesto. Cambridge UK. Cambridge University Press

Rutherford, J. F. (1985) .Lessons from five countries. In M.S. Klein \& J.F. Rutherford (Eds.). Science Education in Global Perspectives: Lessons from Five Countries. Pg. 207-231 Boulder, Colo. Westview Press

Rutherford, M. (1993). Making scientific language accessible to science learners. Paper presented at the First Annual Meeting of the South African association for Research in Mathematics and Science Education (SAARMSE), Grahamston .South Africa.

Smith .L.T. (1999) Decolonizing Methodologies. Research and Indigenous People. Zed Books. London

Solzhenitsyn, A; (1995) .Cited in Cobern W.W. Science and a Social Constructivist View of Science Education. In W.W. Cobern (Ed.) SocioCultural Perspectives on Science Education: An International Dialogue. pg. 7-23. Kluwer Academic Publishers .Dordretcht .The Netherlands.

Strevens, P. (1980). Teaching English as an International Language. Oxford .Permagon Press

Tema, B. O. (2002). Science Education and Africa's Rebirth. In C.A. Odora Hoppers (Ed.) Indigenous Knowledge and Intergration of Knowledge Systems. Towards a Philosophy of Articulation. Pg 128-140. New Africa Books(Pty) Ltd. Clarement. South Africa.

Wackerhausen (1999). Conference Papers, Ministry of Education, Denmark. Pa Sporet at Praksis

Warren ,D.M. (1991). Using indigenous knowledge in Agricultural Development. World Bank Discussion Paper 127. Washington DC. World Bank

Warren, D. M. ;Von Liebenstein G and Slikkerveer ,L. (1993) .Networking for indigenous knowledge. Indigenous Knowledge and Development Monitor $1(1), 2-4$.

Watanabe, M. (1974). The Conception of Nature in Japanese Culture. Science, 188(4122) 279-282. 